\title{
Fluid escape structures as possible indicators of past gas hydrate dissociation during the deposition of the Barremian sediments in the Recôncavo Basin, NE, Brazil
}

\author{
Estruturas de escape de fluidos como possíveis indicadoras de \\ uma paleo-dissociação de hidratos de gás durante a deposição de \\ sedimentos do Barremiano na Bacia do Recôncavo, NE, Brasil \\ Antonio Fernando Menezes Freire ${ }^{1 *}$, Carlson de Matos Maia Leite ${ }^{2}$, \\ Flávio Miranda de Oliveira², Márcio Ferreira Guimarães², Paulo da Silva Milhomem², \\ Raphael Pietzsch ${ }^{3}$, Roberto Salvador Francisco d'Ávila ${ }^{4}$
}

\begin{abstract}
Empty elliptical vesicles are observed in outcrops of Barremian very fine clayey sandstone to siltstone lacustrine slurry deposits of the Pitanga Member (Maracangalha Formation), exposed in the Maré Island, Southern Recôncavo Basin, Brazil. These sedimentary features have been traditionally interpreted as water escape structures triggered by the diapirism of the underlying shales of the Candeias Formation. This work proposes that vesicles were generated during massive gas hydrate dissociation as a result of tectonic activity in a paleolake system. Tectonic uplift would have triggered both the reduction of the confining pressure as well as an increase in lake bottom temperature, resulting in the instability of gas hydrate and causing intense release of both methane - or carbon dioxide $\left(\mathrm{CO}_{2}\right)-$ and water. On one hand, this proposal has a strong impact on paleoenvironmental interpretations, giving support to the current hypothesis that rocks related to the Pitanga Member would have been deposited under water columns deep enough for gas hydrate formation and subsequent dissociation. On the other hand, it provides new insights on the genesis of fluid escape structures in sedimentary rocks, both lacustrine and marine, providing a paleobathymetric indicator.
\end{abstract}

KEYWORDS: Fluidization; Gas hydrates; Maracangalha Formation; Pitanga Member; Recôncavo Basin; Vesicles.

\begin{abstract}
RESUMO: Vesiculas elípticas ocas são observadas em afloramentos de arenitos argilosos muito finos e siltitos Lacustrinos do Membro Pitanga da Formação Maracangalha, expostos na Ilha de Maré, sudeste da Bacia do Recôncavo, Estado da Bahia, Brasil. Essas rochas foram depositadas em condiçōes subaquosas e são consideradas depósitos gravitacionais do tipo slurry. Essas feiçōes têm sido tradicionalmente interpretadas como sendo estruturas de escape de água, resultado da ação do diapismo de folhelhos sotopostos da Formação Candeias. Este trabalho propöe que as vesiculas foram geradas durante uma intensa dissociação de hidratos de gás em resposta à atividade tectônica existente naquele sistema lacustre. O soerguimento tectônico do fundo do lago teria propiciado a redução da pressáo confinante nos poros sedimentares, bem como o aumento de temperatura nas águas de fundo, resultando na instabilidade dos hidratos de gás contidos nas porçôes rasas dos sedimentos e causando uma violenta liberação de metano — ou gás carbônico $\left(\mathrm{CO}_{2}\right)$ — e água. Se correta, esta proposta tem um grande impacto na interpretação paleoambiental da Bacia do Recôncavo, uma vez que corroborará com a hipótese corrente de que as rochas do Membro Pitanga teriam sido depositadas em ambientes profundos, suficientes para a formaçāo de hidratos de gás e a consequente dissociação em periodo de soerguimento. Por outro lado, permite uma interpretaçáo adicional acerca da gênese de estruturas de escape de fluidos em rochas sedimentares, lacustres ou marinhas, servindo como um potencial indicador de paleobatimetria.
\end{abstract}

PALAVRAS-CHAVE: Bacia do Recôncavo; Fluidizaçāo; Formaçāo Maracangalha; Hidratos de gás; Membro Pitanga; Vesículas.

\footnotetext{
${ }^{1}$ Instituto de Geociências da Universidade Federal Fluminense - UFF, Niterói (RJ), Brazil. E-mail: afmfreire62@gmail.com

${ }^{2}$ Petrobras, Unidade de Operação da Bahia - UO-BA. Salvador (BA), Brazil. E-mails: cmml@petrobras.com.br, fmo@petrobras.com.br, milhomem@petrobras.com. br, marciog@petrobras.com.br

${ }^{3}$ Petrobras Research and Development Center - CENPES, Rio de Janeiro (RJ), Brazil. E-mail: pietzsch@petrobras.com.br

${ }^{4}$ Petrobras Exploration and Production - E\&P/EXP, Rio de Janeiro (RJ), Brazil. E-mail: rdavila@petrobras.com.br

*Corresponding author.

Manuscript ID: 20160090. Received in: 07/21/2016. Approved in: 01/05/2017.
} 


\section{INTRODUCTION}

Discussions regarding the formation and dissociation of gas hydrates in oceans, seas and permafrost environments are widely described in the literature (Collett, 2002; Freire, 2010; Haacke et al., 2009; Hyndman \& Davis, 1992; Matsumoto, 2005; Matsumoto et al., 2009). However, studies concerning fossil gas hydrate formation and dissociation in both marine and lacustrine environments are rare, since the evidences of such processes are not based on direct observations, as those of present day gas hydrate occurrences. The main challenge of this work is to compare features possibly related to past gas hydrate dissociation in the Recôncavo Basin, NE Brazil, which occurred at about 125 and $130 \mathrm{Ma}$ Before Present (BP), with present-day occurrences. The evidence provided here is not based on the occurrence of gas hydrates themselves, but relies on the observation of structures, suggesting the presence of ancient gas hydrates.

This article proposes a possible alternative interpretation for the origin of decimeter to meter-sized vesicles observed in outcrops of very fine clayey massive sandstone to siltstone deposits of the Pitanga Member of the Maracangalha Formation, in the Maré Island, Recôncavo Basin (Fig. 1). These features have been traditionally interpreted as water escape structures, related to a dewatering process caused by the diapirism of the underlying Candeias Formation shales (Barbosa da Silva et al., 2007).

The occurrence of isolated vesicles suggests that intraformational captive over-pressured fluids could have expanded the sedimentary primary porosity, but remained trapped due to the high density, plasticity and low permeability of the host fine to very fine clayey sandstone. During shale diapirism and the related uplift of the lake floor, pressure release and temperature increase would have favored gas hydrate dissociation and the consequent release of both methane and water, leading to the widespread formation of vesicles. A similar interpretation was provided by Machel et al. (2014), who related episodic fluid flow and dolomitization by methane-bearing pore water of marine parentage in an accretionary prism setting at Barbados, West Indies.

Our data and findings have a strong impact on paleoenvironmental interpretations, giving support to the assumption that the Pitanga Member sandstones would have been deposited under deep water conditions, suitable for gas hydrate formation. On the other hand, this hypothesis introduces a new perspective for understanding the development of fluid escape structures in sedimentary rocks, either lacustrine or marine, providing a paleobathymetric indicator. Another contribution of this work is the inference of gas hydrates dissociation processes in Barremian strata. Up to now, the oldest occurrences

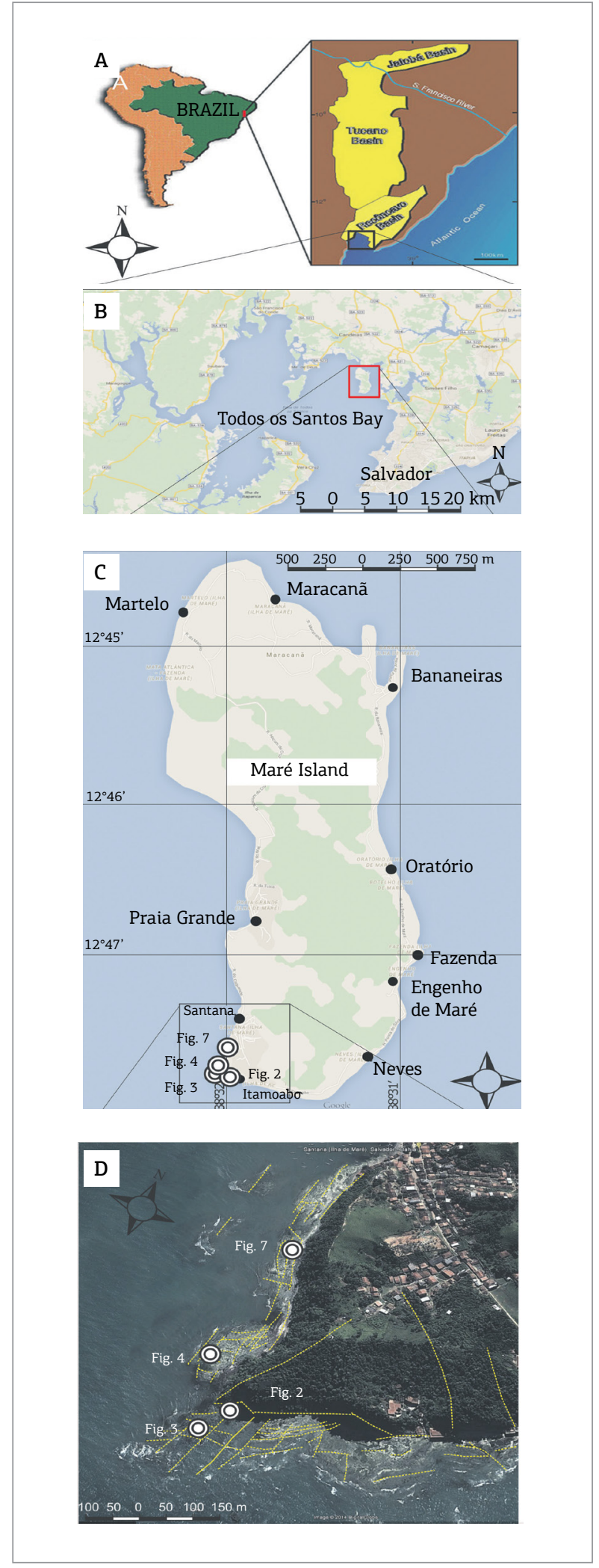

Figure 1. (A) Location map of the Recôncavo Basin; (B) Location map of Todos os Santos Bay and Maré Island (Google Maps); (C) Maré Island and the study area. Location of figures 2, 3, 4 and 7 is given for reference; (D) Image from Google Earth depicting structural lineaments (yellow dotted lines) on the outcrop at the sea level. 
were reported by Haq (1998), in Paleocene rocks, and the ones studied by Jenkyns (2010), based on carbon isotope data related to Oceanic Anoxic Events (OAE), such as the Early Toarcian OAE, another warm period which occurred ca.183 Ma ago (Hesselbo et al., 2007; Jenkyns, 2003, and references therein).

\section{Gas Hydrates Background}

Natural gas hydrates are solids formed from a combination of water and one or more hydrocarbon or non-hydrocarbon gases, resembling packed snow or ice. The gas molecules are trapped within a crystal structure (cage) composed of water molecules, which is the reason why gas hydrates are also known as clathrates (Sloan Jr., 2003).

Gas hydrates are stable only under specific pressure-temperature, gas composition, and salinity of ambient waters. Natural hydrates commonly contain large amounts of methane (> 99\%) (Sloan Jr., 2003), in which case they are also called methane hydrates. Experimental analyses indicate that $1 \mathrm{~m}^{3}$ of hydrate dissociates at ambient temperature and pressure to form $164 \mathrm{~m}^{3}$ of natural methane and $0.8 \mathrm{~m}^{3}$ of water (Kvenvolden, 1993).

The origin of methane in hydrates can be either thermogenic or biogenic, and seeps are quite common in oceanic hydrate provinces, where this gas is usually released to the sea floor by dispersed seepage over large areas, e.g. in pockmarks or crater fields (Ginsburg, 1998; Miller et al., 2015), or by more focused escapes along shallow faults (Freire et al., 2011; Mienert \& Posewang, 1999; Suess et al., 1999).

\section{Geologic Setting}

The Recôncavo Basin is located in Bahia State, NE Brazil, occupying an area of ca. 11,500 km² (Fig. 1A). The structural configuration of the basin is related to the extensional stresses that prevailed from the Late Jurassic to the Early Cretaceous, leading to the fragmentation of the Gondwana and the opening of the South Atlantic Ocean. The basin is part of an aborted continental rift system and displays a NE-SW trending hemi-graben geometry, with the border fault located to the southeast (Fig. 1A - Barbosa da Silva et al., 2007). Since the 1950 's, oil and gas exploration, and development activities have raised a solid knowledge about its sedimentary records and the basin evolution, from the pre-rift to syn-rift and post-rift stages (Netto \& Oliveira, 1985; Magnavita, 1992; Barbosa da Silva et al., 2007).

The rift phase comprises strata of Early Berriasian (ca. $144 \mathrm{Ma}$ ) to Early Aptian ages (ca. $124 \mathrm{Ma}$ - Barbosa da Silva et al., 2007), depicting an initial lacustrine setting, followed by deltaic and fluvial-deltaic deposition as the basin was filled. Basinal shales and deposits related to turbidites and mass gravity flows characterize the early rift lacustrine strata of both Candeias and Maracangalha formations (Netto \& Oliveira, 1985; Magnavita, 1992).

Gravity flows triggered by earthquakes (Raja Gabaglia, 1991) are recorded by turbidite lobes and channel sandstones as well as slurry deposits, defining sequences of sandstones, sandy lutites and siltstones (Caixeta, 1988). The Caruaçu Member of the Maracangalha Formation is primarily composed of stratified and massive (slurry) turbidite sandstones. The Pitanga Member, on the other hand, is essentially represented by tens to hundreds of meters of thick slurry deposits, and subordinate deformed fine-grained stratified sandstones. The deposition of both members was contemporaneous with the propagation of listric faults induced by lutokinesis of lacustrine shales and mudstones of the Candeias and Maracangalha formations (Barbosa da Silva et al., 2007).

The mini-basins developed in the hanging wall blocks of the listric faults were the preferential sites for the deposition of gravity flows. Post-depositional fluidization process would have been driven by the differential load associated with the amalgamation of sandy deposits in the mini-basins (Scherer, 2007).

\section{METHODS}

\section{Rock sampling and outcrop description}

Six rock samples were collected in the Maracangalha formation outcrop at Maré Island, from the walls of several vesicles, for mineralogical, chemical and stable isotope characterization. For biochronostratigraphic purposes, using ostracode biozonation, two samples of the Maracangalha formation outcrop, at Maré Island, were collected, corresponding to intervals of millimeter to centimeter thick medium to dark gray shale beds intercalated in the turbidite section (Fig. 2). For comparison, ostracods of the same biozone were also collected for isotope analysis from cuttings of an oil well, located $77 \mathrm{~km}$ away from outcropping vesicles. Dip-directions of faults and fractures (Fig. 3A) were measured using a Clar compass, and the dataset was displayed in a stereonet diagram for comprehensive presentation (Fig. 3B).

\section{Thin sections}

Six thin sections were prepared from the rock samples collected from the vesicle walls. They were studied under a ZEISS Axio Imager Z2m petrographic microscope. Carbonates - dolomite and calcite - were classified according to their characteristic reaction colors with alizarin reagent. 


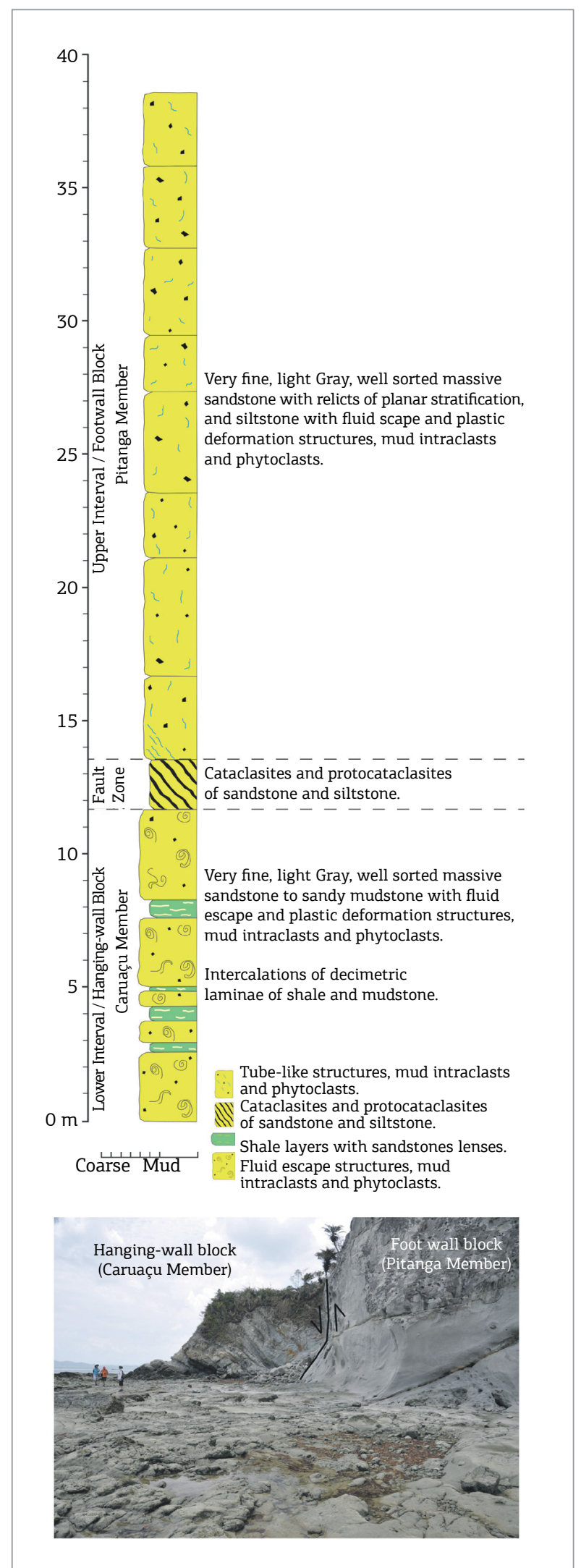

Figure 2. Outcrop stratigraphic column showing the three intervals described.

\section{$\mathrm{X}$-ray diffractometry, carbonate content, scanner electronic microscope with energy dispersive spectroscopy stable carbon and oxygen isotope analyses}

Two representative rock samples (I and II - Figs. 3C and $3 \mathrm{D}$ ), collected from the vesicle walls, were analyzed for mineralogical and chemical determination using $\mathrm{X}$-ray diffractometry (XRD), calcimetry and carbon isotope analysis. The samples were cleaned of living faunal incrustations (barnacles) and first examined through scanner electronic microscope with energy dispersive spectroscopy (SEM-EDS). The samples were then ground for whole rock XRD. The powdered samples were also used for measuring the carbonate content and performing isotope analyses.

For SEM procedures, the fresh irregular surface of each sample was covered with palladium-gold, using an EMITECH K750X vacuum apparatus. The samples were analyzed by a JEOL JSM6490LV SEM, as images of secondary electrons operated in high vacuum at $20 \mathrm{kV}$ and with a work distance of $10 \mathrm{~mm}$. The EDS microanalysis was obtained from an OXFORD INCA, coupled to the SEM. The semi-quantitative compositional tables include the weight percentage, the atom percentage and the elements in the form of oxides - calculated stoichiometrically —, normalized to $100 \%$.

For the bulk rock XRD analysis, the samples were ground by a McCRONE mill. The powdered samples were pressed, without orientation, in a support container. These were run on a RIGAKU D/MAX-2200/PC difractometer, using copper $\mathrm{k}$-Alfa radiation at $40 \mathrm{kV}$ and $40 \mathrm{~mA}$ current filament, and 2, 0.3 and $0.6 \mathrm{~mm}$ slits. The goniometer speed was set to 2.33 degrees per minute. The quantitative mineralogy was obtained with the help of the Jade 5 software, by Materials Data Inc., and the minerals data bank PDF-2 from the International Centre for Diffraction Data. A quantitative analysis was performed by the Rietveld method, using the FullProf (version 5) software.

Isotope analyses were made online in bulk rock, using a Delta V Plus mass spectrometer, coupled to a dual inlet Kiel IV preparation unit for carbon dioxide $\left(\mathrm{CO}_{2}\right)$ extraction. Samples were treated with ortophosphoric acid $\left(\mathrm{H}_{3} \mathrm{PO}_{4}\right)$ in vacuum atmosphere at $70-75^{\circ} \mathrm{C}$ during $3 \mathrm{~min}$. The ${ }^{13} \mathrm{C} /{ }^{12} \mathrm{C}$ and ${ }^{18} \mathrm{O} /{ }^{16} \mathrm{O}$ ratios were measured in parts per mil (\%o), related to the Pee Dee Belemnite (PDB) standard (Sharp, 2007; Hoefs, 2009). The analytical reproducibility of replicate standards (NBS-19) and samples was, on average, $0.1 \%$ for both carbon and oxygen isotope analyses. 


\section{Ostracode biozonation}

$100 \mathrm{~g}$ of rock were first crushed and then treated with hydrogen peroxide (130 vols.) for oxidation of organic matter. After washing through 0.125 and $1.0 \mathrm{~mm}$ sieves and drying, the fractions retained in the latter were selectively hand-picked for an ostracode analysis under a Zeiss Discovery V8 Stereomicroscope with reflected light.

\section{RESULTS}

\section{Outcrop description}

Fine clayey sandstone and siltstone of the Pitanga and Caruaçu members of the Maracangalha Formation are exposed in the southern part of the Maré Island, between the villages of Santana, to the north, and Itamoabo, to the

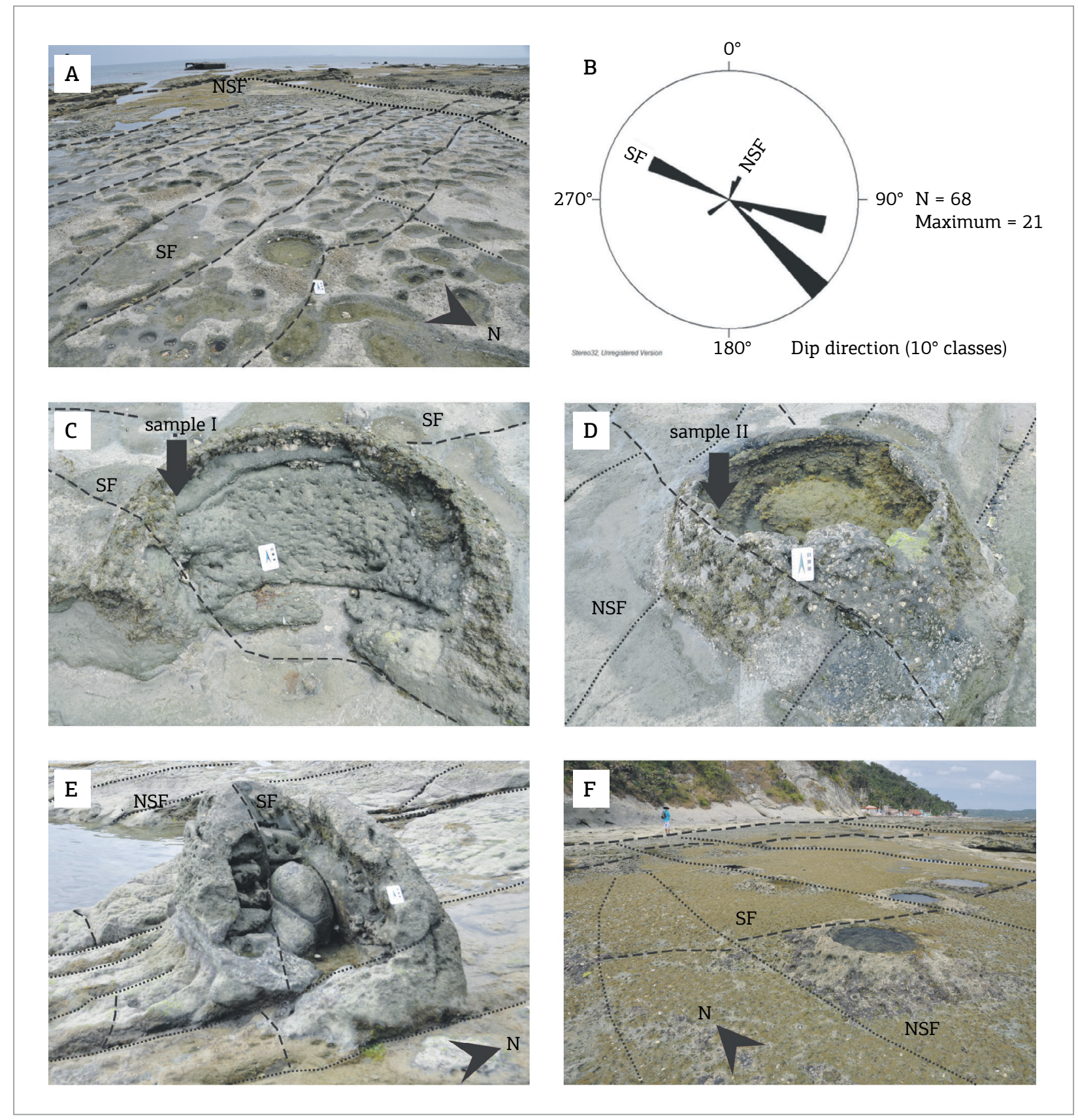

Figure 3. (A) Scattered empty vesicles on the floor of the outcrop at the sea level. Note the presence of the systematic fractures and non-systematic fractures; (B) Stereonet diagram showing both systematic fractures and non-systematic fractures directions; (C and D) Empty vesicles on the floor of the outcrop. Location of samples I and II, collected from the wall of two different vesicles, is shown; (E) A big vesicle with a small vesicle inside; (F) Empty vesicles with volcano-like shape surrounded by several other small empty vesicles. 
south (Figs. 1B to 1D). The outcrop is ca. $240 \mathrm{~m}$ long, $39 \mathrm{~m}$ high and comprises two distinct sedimentary intervals, separated by a normal fault zone trending NE-SW and dipping to NW (Fig. 2). The footwall block represents the Pitanga Member, with a thickness of ca. $25 \mathrm{~m}$, consisting of 0.5 to $2.6 \mathrm{~m}$ thick sandstone beds intercalated with decimetric layers of siltstone and shale. The sandstone is very fine, well sorted, light gray, friable and massive. Planar stratification develops locally. Fluid escape structures, plastic deformation features, mud intraclasts and phytoclasts are common in the entire basal interval. Light to dark gray siltstone and shale layers are disposed in laminae of 0.2 to $0.6 \mathrm{~m}$ thickness.

The intermediate interval is ca. $2 \mathrm{~m}$ thick (11.7 and $13.7 \mathrm{~m}$ - Fig. 2) and is constituted of cataclasites and protocataclasites of very fine light gray sandstone to siltstone. The hanging-wall block represents the Caruaçu Member and is rotated and curved, forming a sin depositional drag adjacent to the slip surface of the fault. The interval has a thickness of ca. $11.7 \mathrm{~m}$ (Fig. 2) and is comprised of light gray, very fine, massive, but locally with planar stratification, sandstone to siltstone in beds of 3.5 to $5.0 \mathrm{~m}$ thickness. Several mud intraclasts are observed in this interval.

Two main sets of fractures occur on the floor of the outcrop (Figs. 3A and 3B):

1. the systematic (continuous) fractures (SF), oriented NE-SW with medium to high dip angles in directions N300-N310, N100 or N140 to N120; and

2. non-systematic (discontinuous) fractures (NSF), with a NW-SE trend and medium to high dip angles to N020-N030 and N230-N240.

Part of the vesicles shows collapsed cores that form craters with walls resistant to waves and tide erosion, probably due to the carbonate cementation (Figs. 3C and 3D), while other vesicles of the outcrop are supported by the presence of dolomite (Figs. 3E and 3F). Vesicles show circular or ellipsoidal geometries with major and minor axes, respectively parallel to the systematic fractures and the dip directions (Figs. 4A and 4B).

\section{Mineralogical \\ characterization of vesicle walls}

Because vesicles are empty, the study was concentrated on the vesicle walls. Petrographic analyses show that the vesicle walls can be classified as sandy lutites to muddy sandstones, according to the textural classification of Folk (1968). The sandy fraction is a subarkose (Folk, 1968), with good textural maturity, composed of fine to very fine quartz (40-50\% modal), plagioclase (10-15\% modal) and K-feldspar (5-10\% modal), as well as trace amounts of biotite and muscovite. XRD data support the petrographic evaluation, providing a mineralogical composition of quartz (54-43\%), plagioclase (12-10\%), dolomite (17-33\%), K-feldspar (6-5\%), clay minerals (11-9\%) and traces of calcite, for samples I and II.

Rare mud intraclasts are observed, but pseudo-matrix replaced by chlorite-smectite and illite-smectite, and accessory minerals consisting of pyrite and leucoxene - is commonly seem (Fig. 5A). Dolomite (15-35\% of the modal composition) has a blocky habit, and occurs either as a cement or in the form of microcrystalline aggregates (Fig. 5B).

Images and microanalyses by SEM-EDS suggest that the dolomite is slightly ferrous, with a $\mathrm{FeO}$ content of up to $4.7 \%$ of the chemical composition (Figs. 5C and 5D).

\section{Biostratigraphy}

Samples collected for biostratigraphy revealed a poor and barely preserved ostracode assemblage. Nevertheless, it was possible to date the rocks as Barremian (Upper Aratu local stage), relating the sedimentary package to the late middle rift phase proprosed by Silva (1993). Cypridea (Morinina?) bibullata bibullata (Wicher, 1959) and species belonging to Reconcavona (Krömmelbein, 1962) were the main taxa recovered. Ostracodes from the same biozone and stratigraphic interval were also collected for comparison from a well, drilled ca. $77 \mathrm{~km}$ to the north. The carapaces were analyzed by SEM/EDS, revealing a calcite and low magnesium $(\mathrm{Mg})$-calcite composition of the external shells, but with manganese $(\mathrm{Mn})$ carbonate cement in the inner side. Unfortunately, the apparently unaltered external side of the carapace could not be retrieved in sufficient amount to be solely representative of the primary shell constitution, and thus the whole material was analyzed for its isotopic composition, including the inner shell content. Hence, isotope results were not used in this study, because of the risk of significant secondary/post-depositional alteration.

\section{DISCUSSION}

Isolated empty elliptical vesicles, observed in the outcrop of Maré Island, have been traditionally interpreted as water escape structures triggered by the diapirism of the underlying shales of the Candeias Formation, in a paleolake system. This work proposes that vesicles were generated during massive gas hydrate dissociation as a result of a tectonic uplift, which triggered both the reduction of the confining pressure as well as an increase in lake bottom temperature, resulting in the instability of gas hydrate and causing intense release of both methane - or $\mathrm{CO}_{2}$ — and water.

However, this work raises two critical points for discussion: the first one is related to the possible existence of gas hydrates 
in tropical rift lakes, considering the temperatures and pressures that characterize such environments; the second one is the likelihood of gas hydrate formations under the general warm greenhouse conditions that prevailed during the Early Cretaceous. The oldest known records of gas hydrates have a Late Paleocene age (Haq, 1998). Nevertheless, Hesselbo et al. (2000) and Sabatino et al. (2009) propose that a significant gas hydrate dissociation could explain a negative $\delta^{13} \mathrm{C}$ excursion, representative of the Toarcian OAE during the Early Jurassic, a known dry and warm period.

Gas hydrates can occur at temperatures significantly above the freezing point of water (up to $19^{\circ} \mathrm{C}$ ) at appropriate pressure conditions (Edmonds et al., 1996). However, pressure and temperature are not the only factors controlling the stability of hydrates. In fact, water salinity and the gas composition are critical parameters to consider for gas hydrate formation and dissociation, once these parameters can shift the gas hydrate stability curve to higher or lower temperatures, at the same pressure (Hardage \& Roberts, 2006). The boundary between free methane and methane hydrate for a pure water system was presented by Kvenvolden
(1993, 1998), as shown in Figure 6. As depicted in this figure, bottom water temperatures between 4 and $20^{\circ} \mathrm{C}$ can provide the necessary conditions for gas hydrate stabilization in depths ranging from 400 to $2,000 \mathrm{~m}$, respectively. A temperature of $4^{\circ} \mathrm{C}$ is typical of present lake and sea bottom waters around the world, due to the density-expansion property of water at this temperature, especially in setting with stratified waters, i.e., no strong bottom water currents (Denny, 2008).

In the Recôncavo Basin, water depths ranging from 400 to $2,000 \mathrm{~m}$ are considered feasible during the major tectonic phase, when a combination of high subsidence rates and low sedimentary supply might have led to a deep lacustrine setting with mass gravity flow deposits, among which are the Pitanga Member massive sandstones (Barbosa da Silva et al., 2007). It is important to consider, however, that lacustrine ostracods, as the ones recovered from the studied outcrop, are not expected to inhabit such deep environments. The assumption that those depths are reasonable for the deposition of the related sediments could be only taken into account by considering a post-mortem transport of the

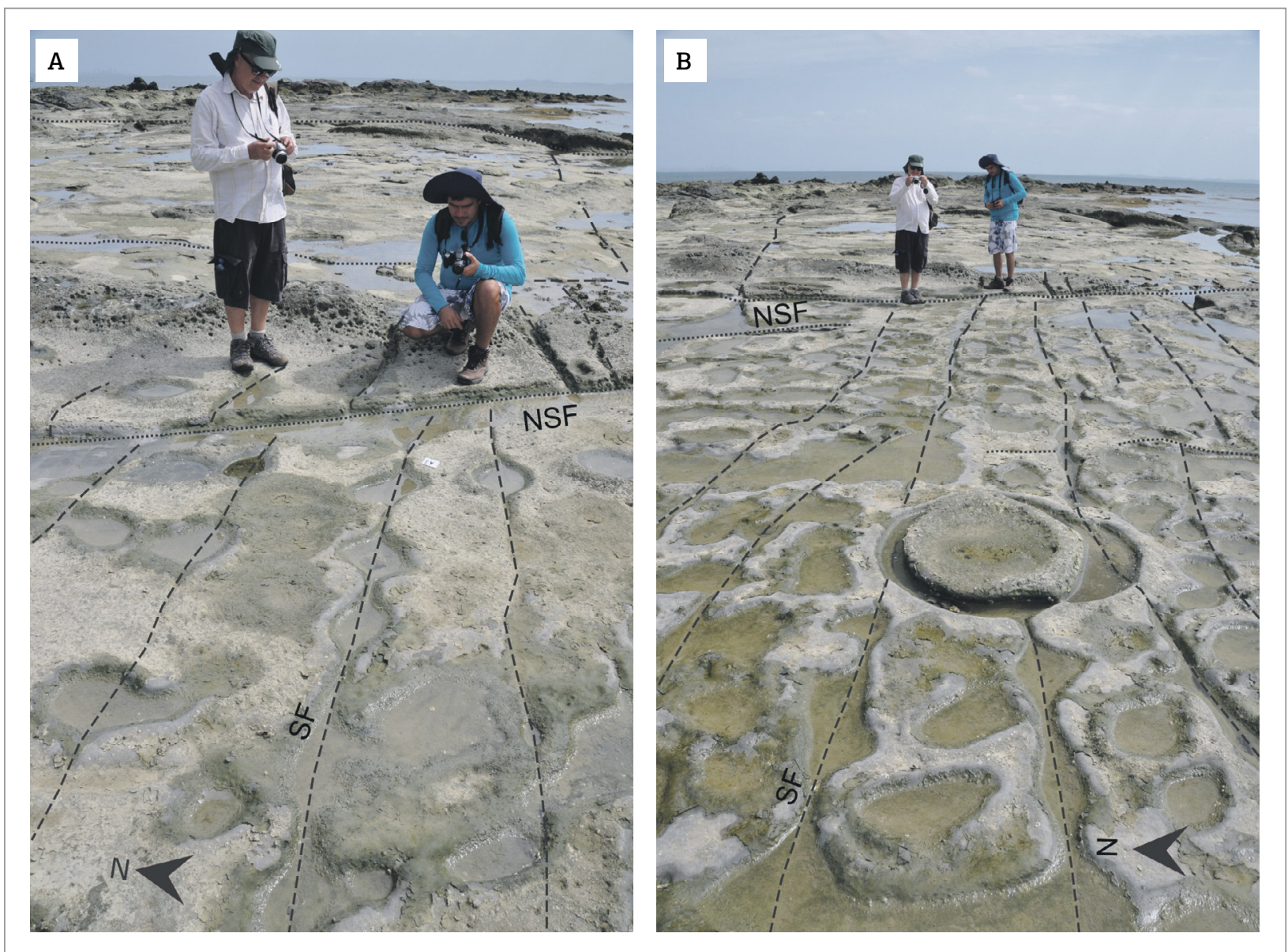

Figure 4. (A and B) Empty vesicles controlled by the structural network. Note that the major axis of vesicles are parallel to the systematic fractures, while the minor axis are parallel to non-systematic fractures. 
carapaces to these deep sites by landsliding and/or turbidity currents. Landslides, slumps and turbidity currents are common during the Maracangalha Formation deposition and could transported allochthone shells, in addition to siliciclastic particles, to deeper environments (Scherer, 2007).

From the Early Berriasian (145.5 to $142.3 \mathrm{Ma}$ ) to the Late Barremian (128.3 to $125.0 \mathrm{Ma}$ ), two important OAE can be recognized: the Faraoni OAE (Late Hauterivian) and the Weissert OAE (Late Valanginian - Jenkyns, 2010). The presence of manganese-bearing carbonate cement filling ostracode shells suggests reducing environmental conditions, typical of methane seep environments (Snyder et al., 2007), as well as in stratified anoxic bottom water lake. Major negative excursions in $\delta^{13} \mathrm{C}$ values occurring together with increases in benthic temperature, as well as lake or sea-level lowering events that reduce hydrostatic pressure, may provide plausible clues to the past behavior of gas hydrates (Haq, 1998).
For these reasons, the gas hydrate formation and dissociation in the Early Cretaceous Recôncavo paleolake is feasible, but speculative, mainly due to the physical absence of hydrates in the present time at the basin. In addition, diagenesis very likely affected the depositional stable carbon and oxygen isotope values of the ostracode shells as suggested by the geochemical data obtained and, therefore, the use of $\delta^{18} \mathrm{O}$ for inferring paleotemperatures within the paleolake would be strongly speculative in this case. For this reason, these data could not be used in this study.

\section{Depositional processes}

The outcrop is mainly represented by very fine sandstones to siltstones deposited as turbidites and slurries (Lowe \& Guy, 2000; Magalhães \& Tinterri, 2010), a geological concept for deposits generated by underwater gravity flows, whose attributes and features are suggestive of a Newtonian and transitional
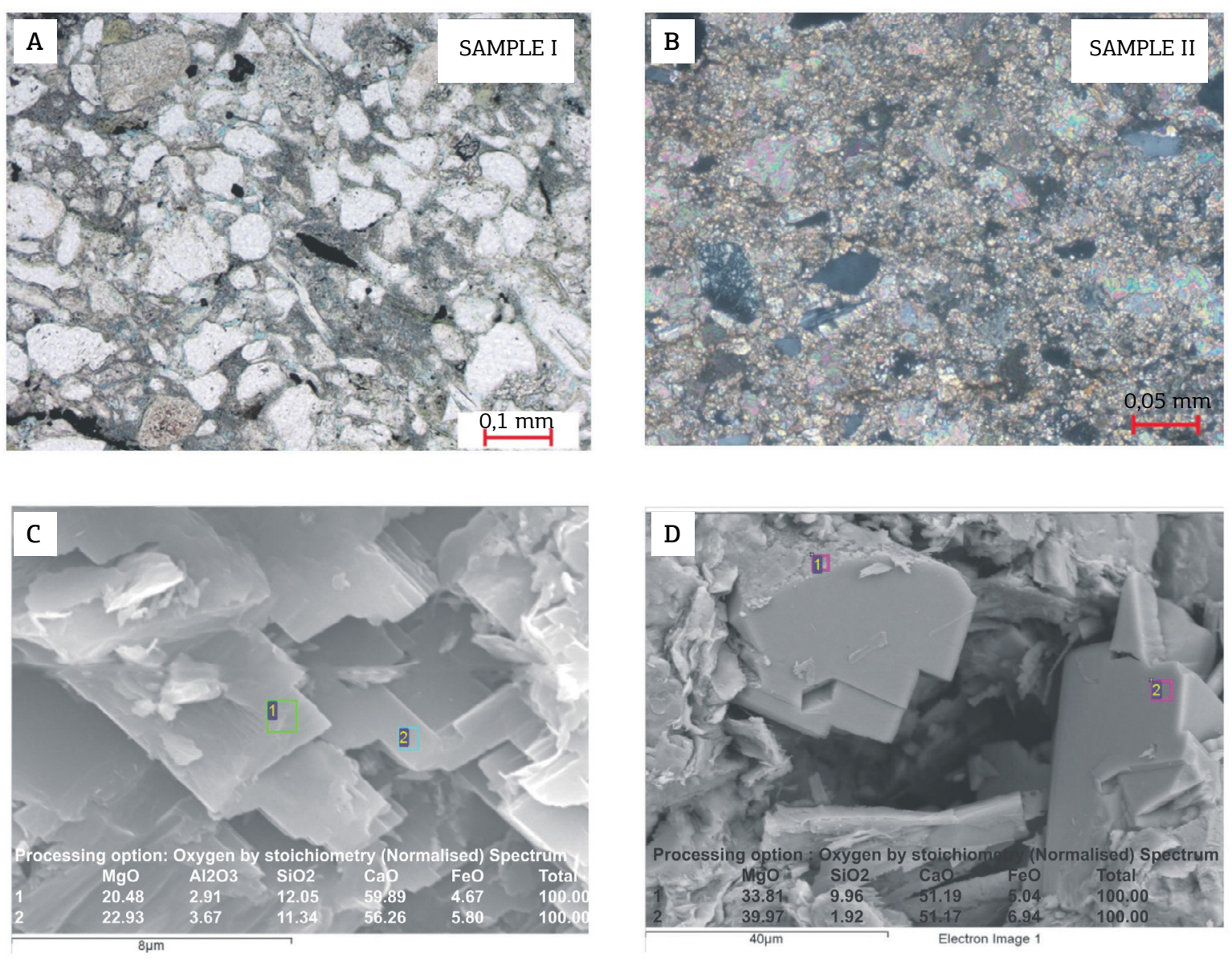

Figure 5. (A) Micro photo of sample I showing rare mud intraclasts (black components) and pseudo-matrix replaced by chlorite-smectite and illite-smectite with pyrite and leucoxene as accessory minerals; (B) Dolomite (15-35\% of the modal composition) has a blocky habit and occur either as a cement or in form of microcrystalline aggregates that replace the clayey pseudo-matrix; ( $C$ and $D$ ) Images and microanalyses by SEM-EDS of samples I and II suggest that the dolomite is ferrous with a FeO content of up to $47 \%$ of the chemical composition. 
rheological behavior, i.e. laminar fluxes and diluted conditions observed in the turbulent flows (Tinterri \& Tagliaferri, 2015).

\section{Vesicles formation}

The presence of mounds, pockmarks and authigenic carbonate nodules is widely considered as an indicator of gas venting and shallow gas hydrate occurrence, even in the absence of recovered gas hydrate (Dickens, 2001; Matsumoto, 2005). Mounds would be related to the formation and growth of gas hydrates and the expansion of pore volume, inducing the uplift of the sediments as a response to the lower hydrostatic pressure compared to the lithostatic pressure of the surrounding sediments (Freire et al., 2012; Matsumoto, 2005). Disturbances in both bottom water pressure and/or temperature, as warm currents, tectonic uplift or sea level/lake level fall can induce the dissociation of gas hydrate. If the disturbance is abrupt, the subsequent hydrate dissociation can be catastrophic, causing a severe dissociation of gas hydrate. In this case, there would be a strong release of methane - or other gases as $\mathrm{CO}_{2}$ - and water into the water body, generating craters (pockmarks) or subaquatic

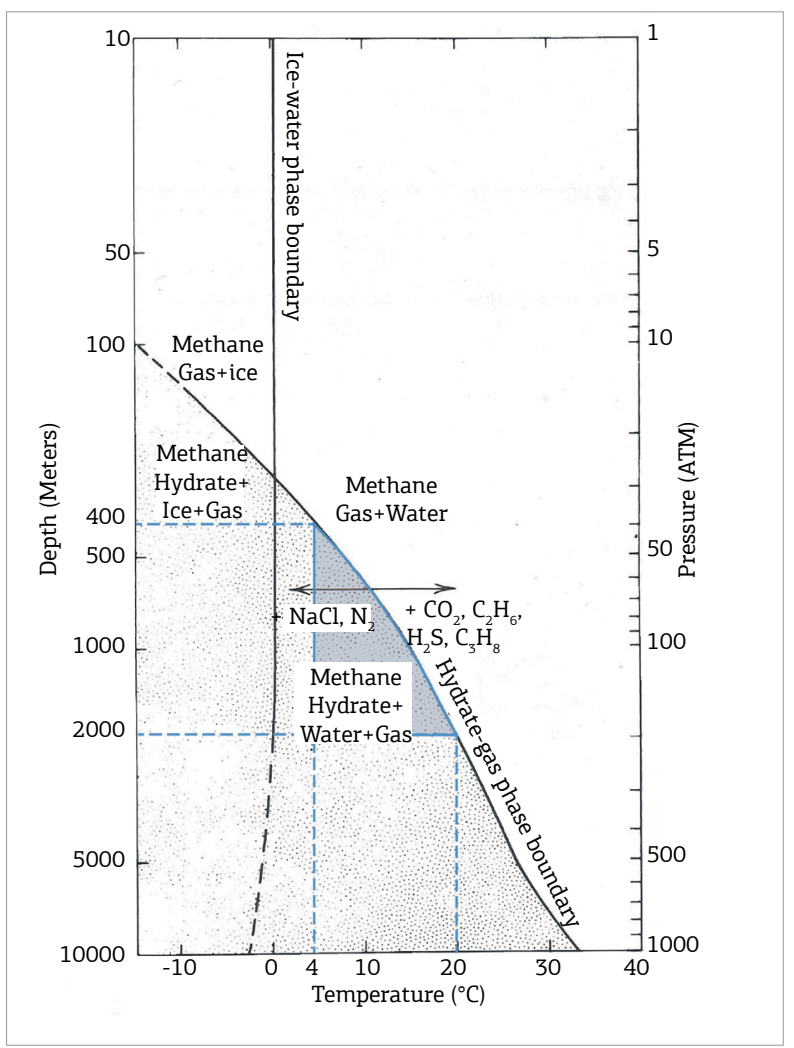

Figure 6. Phase diagram for gas hydrate stability in pure water, showing that gas hydrate is stable between $4^{\circ} \mathrm{C}$ and $20^{\circ} \mathrm{C}$. Such temperature range would correspond to water depths of $400 \mathrm{~m}$ to $2,000 \mathrm{~m}$ (modified from Kvenvolden, 1993, 1998). pingoes at the bottom of the sea or lake (Matsumoto, 2005; Serié et al., 2012).

Almost all craters, pingoes or elliptical vesicles described in the Pitanga Member sandstone that outcrop in the Maré Island are empty (Figs. 7A to $7 \mathrm{C}$ ), with no visible material inside. This work proposes that gas hydrates were formed due to the presence of methane - or $\mathrm{CO}_{2}-$ at the time of sedimentary deposition, trapped within sedimentary porosity (Figs. 8A to 8D). Authigenic dolomite cement in carbonate chimneys, slabs and ridges has been reported by Orpin (1997) as derived from aquifer-forced ground water seepage. This interpretation supports the water escape origin presented by Barbosa da Silva et al. (2007) for the vesicles.

However, vesicles are isolated and they are not connected, as expected during water escaping. Thus, the dissociation of isolated gas hydrate aggregates is quite suitable to explain the isolated vesicles, given the host rock depositional environment and the subsequent climatic fluctuations and tectonic activity in the Recôncavo paleolake, despite the lack of reliable carbonate carbon and oxygen isotopic data to sustain this theory.

The wall of each empty vesicle has a hard surface resistant to erosion by present sea waves (Figs. 3C to $3 \mathrm{~F}$ ) and related to the cementation of quartz grains by ferrous dolomite, as a possible consequence of the anaerobic oxidation of the released methane (AOM), after gas hydrate dissociation. The hard ground on the vesicle wall is the result of AOM. This is the interface between methane - within the vesicle - and the interstitial water - outside vesicle, within the pores of sediment.

AOM occurs within ocean floor sediments, where seawater enriched in sulphate meets methane formed at both methanogenesis and/or thermogenesis zones. This interface is named sulphate-methane transition (SMT) (Dickens, 2001), and there, the precipitation of sulphide and carbonate is common, due to a reduction of $\mathrm{pH}$, which can explain the higher total sulphur content and the presence of authigenic carbonate nodules in shallow sediments of mounds and pockmarks around the world. The AOM can be represented by the Equation 1:

$\mathrm{CH}_{4}+\mathrm{SO}_{4}^{2-}+\left(\mathrm{Ca}^{+2}+\mathrm{Mg}^{+2}\right) \rightarrow(\mathrm{Ca}, \mathrm{Mg}) \mathrm{CO}_{3}+\mathrm{H}_{2} \mathrm{~S}+\mathrm{H}_{2} \mathrm{O}(1)$

Thus, AOM reactions are controlled by the concentrations of $\mathrm{CH}_{4}, \mathrm{SO}_{4}^{2-}$ and dissolved ions. In open seawaters, the flux of methane will rule the process, once sulphate concentration is constant, ca. 2,700 ppm on average (Table 1) (Livingstone, 1963). The higher the methane flux, the stronger the AOM, and the shallower the SMT will be, because the flux pushes the boundary 

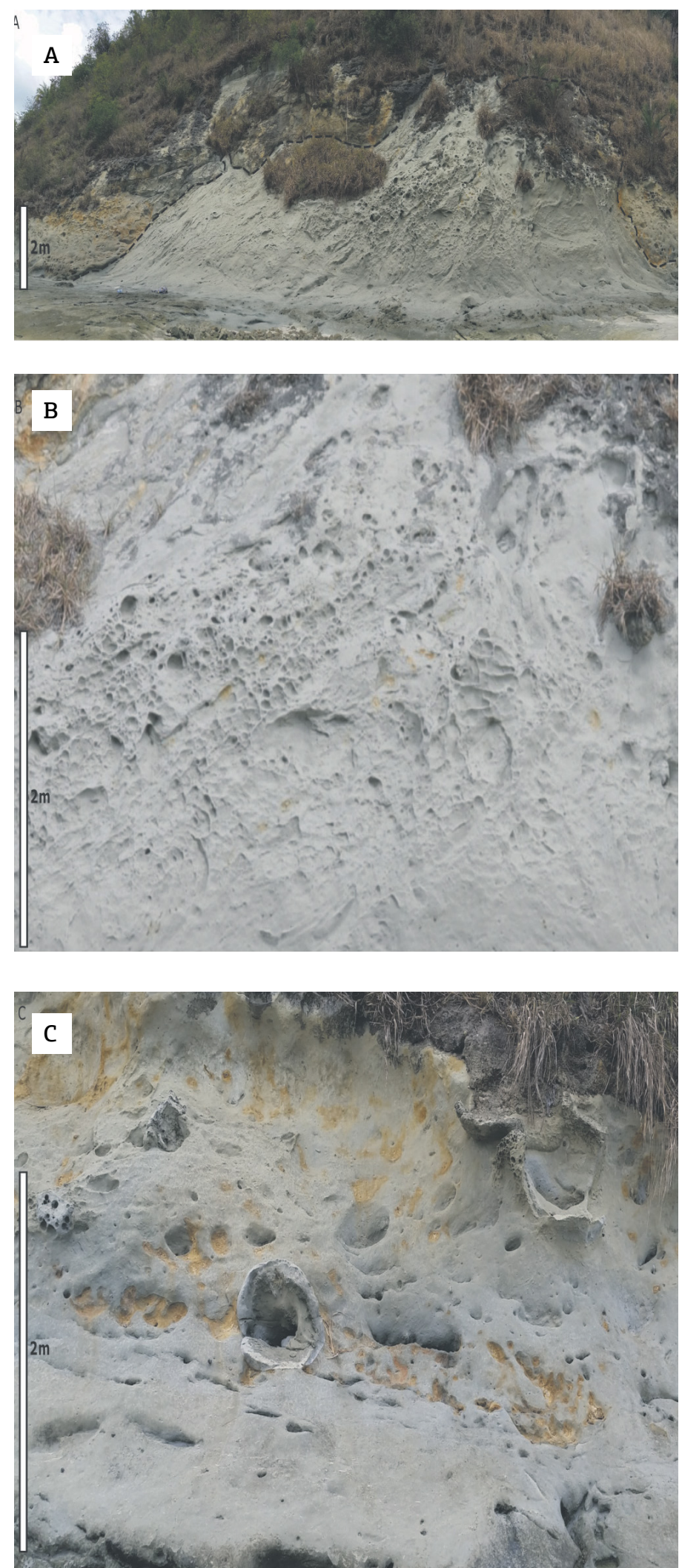

Figure 7. Progressive zoom in part of the outcrop (A, B and C) revealing that craters, pingoes or elliptical vesicles, observed in the Pitanga Member sandstone, are empty and have different sizes and geometries. 

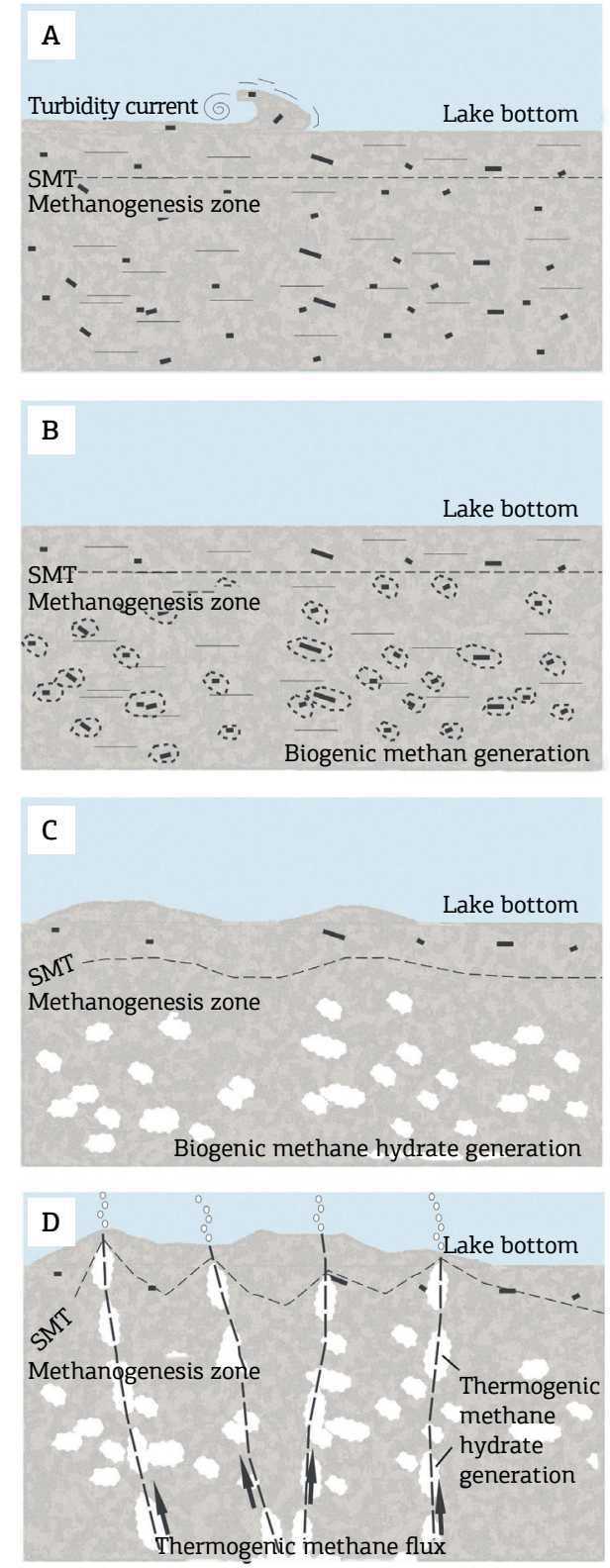

Figure 8. Schematic diagram showing a model for the vesicles formation: $(A)$ very fine sand to silt and terrestrial organic matter deposited by turbidity currents or slurry flows. At the same time, a methanogenesis zone is developed below a methane-sulfate transition zone; (B) Organic matter is degraded generating biogenic methane within the methanogenesis zone. The produced gas expands but still remains trapped within the sediment because of the low sedimentary permeability and porosity of the muddy sandstone; (C) Growth of biogenic gas hydrate within the porous space increases sedimentary volume, pushing the lake floor and generating mounds; (D) Diapirism of the underlying Candeias Formation shales triggers the uplift of the Pitanga Member sandstone. High thermogenic methane fluxes migrate through faults and fractures to the lake floor, causing plumes to form in the water column. upwards (Freire, 2010; Paull et al., 1998). As a consequence of the higher sulphate concentration in seawater, the AOM generated by intense and massive gas hydrate dissociation is well developed due to the larger volume of methane delivered. Accordingly, there is a strong increase in alkalinity which, in turn, favors the precipitation of authigenic carbonates.

The sulphate concentration in freshwater lakes is 245 times lower than in seawater (Table 1), showing an average concentration of ca. $11.2 \mathrm{ppm}$ (Livingstone, 1963). Therefore, AOM reactions in these freshwater systems will be weak and will not depend only on methane concentration, but also on the concentrations of calcium ions $\left(\mathrm{Ca}^{2+}\right)$ and magnesium ions $\left(\mathrm{Mg}^{2+}\right)$. In seawater, the average concentrations of these ions are, respectively, 410 and 1,350 times higher than in freshwater (Table 1) (Livingstone, 1963), reinforcing the weaker character of AOM in the latter. Nevertheless, the precipitation of aragonite and calcite seems to be favored in more oxic environments with both high sulphate concentration and alkalinity. On the other hand, the crystallization of $\mathrm{Mg}$-calcite and dolomite preferentially occur under slightly more anoxic conditions, with lower $\mathrm{SO}_{4}{ }^{2-}$ content as well as a lower total alkalinity (Greinert et al. 2001), conditions observed in freshwater lakes. The presence of manganese carbonate cement within ostracode shells would corroborate this assumption.

The precipitation of authigenic carbonates may just involve dolomite and $\mathrm{Mg}$-calcite cement, filling the sedimentary porosity, as a late diagenetic process (Figs. 5A and $5 \mathrm{~B})$. Moreover, the presence of hydrogen sulfide $\left(\mathrm{H}_{2} \mathrm{~S}\right)$, as a product of AOM, implies that pyrite, siderite or ankerite,

Table 1. Mean composition of freshwaters of the world (Modified from Livingstone, 1963).

\begin{tabular}{l|c|c|c}
\hline Continent & $\begin{array}{r}\mathrm{SO}-2 \\
(\mathrm{ppm})\end{array}$ & $\begin{array}{c}\mathrm{Ca}+2 \\
(\mathrm{ppm})\end{array}$ & $\begin{array}{c}\mathrm{Mg}+2 \\
(\mathrm{ppm})\end{array}$ \\
\hline Africa & 13,5 & 12,5 & 8,0 \\
\hline Asia & 8,4 & 18,4 & 5,6 \\
\hline South America & 4,8 & 7,2 & 1,5 \\
\hline North America & 20,0 & 21,0 & 5,0 \\
\hline Europe & 24,0 & 31,1 & 5,6 \\
\hline Australia & 11,2 & 15,0 & 4,1 \\
\hline World fresh water & 2700,0 & 410,0 & 1350,0 \\
\hline Seawater & 245 times & 27 times & 330 times \\
\hline seawater vs. fresh water & & 3,7 \\
\hline
\end{tabular}


a calcium $(\mathrm{Ca})$, iron $(\mathrm{Fe})$, magnesium $(\mathrm{Mg})$ or manganese $(\mathrm{Mn})$ rhombohedral carbonate (Figs. 5C and 5D), can be formed if dissolved $\mathrm{Fe}$ is available.
According to Livingstone (1963), the waters of Lake Baikal (Central Siberia) have similar concentrations of $\mathrm{SO}_{4}^{-2}$ (Table 2) both on the surface and at depths greater than

Table 2. Chemical composition of several lake waters of the world (Modified from Livingstone, 1963).

\begin{tabular}{|c|c|c|c|c|c|}
\hline Lake & Continent & Country & s04-2 (ppm) & $\mathrm{Ca}+2(\mathrm{ppm})$ & $\mathrm{Mg}+2(\mathrm{ppm})$ \\
\hline Galumué & Africa & Angola & 82,7 & 4,3 & 16,4 \\
\hline Legume & Africa & Angola & 39,7 & 5,4 & 4,4 \\
\hline Nhajosae & Africa & Angola & 10,8 & 1,3 & 2,1 \\
\hline Kivu & Africa & Congo & 32,4 & 8,1 & 122,0 \\
\hline Tanganyika - sup & Africa & Congo & 4,3 & 11,9 & 41,6 \\
\hline Tanganyika - 700m & Africa & Congo & 4,0 & 15,2 & 43,7 \\
\hline Bosumtwi & Africa & Ghana & 6,0 & 12,0 & 28,0 \\
\hline Baringo & Africa & Kenya & 40,0 & 22,0 & 2,0 \\
\hline Crater & Africa & Kenya & 46,0 & 13,0 & 36,0 \\
\hline Nakuru & Africa & Kenya & 253,0 & 10,0 & trace \\
\hline Nalvalsha & Africa & Kenya & 17,0 & 16,0 & 7,0 \\
\hline Rukwa & Africa & Rodhesia & 2,9 & 12,2 & 4,6 \\
\hline Edward & Africa & Uganda & 24,5 & trace & 13,3 \\
\hline Salt & Asia & India & 80,7 & 37,7 & 92,0 \\
\hline Niris & Asia & Iran & 301,0 & 61,0 & 148,0 \\
\hline Haruna & Asia & Japan & 76,9 & 15,3 & 3,8 \\
\hline Ushtagan & Asia & Kazakhstan & 791,0 & 39,7 & 10,9 \\
\hline Baikal - sup & Asia & Mongolia & 4,9 & 15,2 & 4,2 \\
\hline Baikal - 1000m & Asia & Mongolia & 4,4 & 15,2 & 4,4 \\
\hline Great & Australia & Australia & trace & 1,5 & 0,5 \\
\hline Upper & Europe & UK & 3,2 & 1,8 & 0,5 \\
\hline Zurich & Europe & Switzerland & 11,1 & 41,0 & 7,2 \\
\hline Erie & North America & Canada & 22,1 & 38,1 & 8,5 \\
\hline Grand & North America & Canada & 6,4 & 3,9 & 3,2 \\
\hline Ontario & North America & Canada & 20,3 & 36,9 & 7,8 \\
\hline Superior & North America & Canada & 4,8 & 14,1 & 3,7 \\
\hline Chapala & North America & Mexico & 12,4 & 2,0 & 1,1 \\
\hline Pátzucuaru & North America & Mexico & 0,2 & 3,2 & 2,5 \\
\hline Balmorbes & North America & US & 555,0 & 38,0 & 0,1 \\
\hline Couchiching & North America & US & 16,8 & 36,0 & 4,8 \\
\hline Dry & North America & US & 8,4 & 42,0 & 14,0 \\
\hline Fort Stocklon & North America & US & 968,0 & 186,0 & 3,5 \\
\hline Nipissing & North America & US & 8,5 & 9,0 & 3,6 \\
\hline Okeechobee & North America & US & 28,0 & 41,0 & 9,1 \\
\hline Simcoe & North America & US & 13,6 & 39,5 & 6,3 \\
\hline Maracaibo & South America & Venezuela & 147,0 & 38,0 & 92,0 \\
\hline
\end{tabular}


$1,000 \mathrm{~m}$ (4.4-4.9 ppm). The same pattern is observed for $\mathrm{Ca}^{+2}$ (15.2 ppm in both cases) and $\mathrm{Mg}^{+2}$ (4.2 and $4.4 \mathrm{ppm}$, respectively). Lake Baikal is the world's largest and deepest rift lake and the only freshwater basin with proven hydrates in the present (De Batist et al., 2002; Vanneste et al., 2001). Gas hydrates in Lake Baikal have been recovered from water depths greater than $420 \mathrm{~m}$ (Vanneste et al., 2001), and consist, essentially, of methane ( $>99 \%$ of the total gas volume) of biogenic origin ( $\delta^{13} \mathrm{C}$ between $-58 \%$ and $-68 \%$ ). Elsewhere in Lake Baikal's hydrate province, sidescan sonar data acquired on these sites show that the lake floor is smooth and flat without craters, pockmarks and other indicators of fluid or gas escape at the lake floor (De Batist et al., 2002). The absence of carbonate nodules in Lake Baikal may reflect the low concentrations of all the compounds necessary for AOM reaction $\left(\mathrm{SO}_{4}^{-2}, \mathrm{Ca}^{+2}\right.$ and $\left.\mathrm{Mg}^{+2}\right)$, with exception of methane, similar to the conditions assumed here for the Recôncavo paleolake.

\section{CONCLUSIONS}

Empty elliptical vesicles are observed in outcrops of Barremian lacustrine turbidites that belong to the Pitanga Member of the Maracangalha Formation, as recorded by exposures of this member in the Maré Island, Southern Recôncavo Basin, Brazil. The vesicles are mostly aligned according to two trends of fractures:

1. the SF, oriented NE-SW with dip angles ranging from medium to high in the directions N300-N310, N100 or N140 to N120; and

2. the NSF, with a NW-SE trend and average dip angles to N020-030 or N230-240.

Empty vesicles show circular or ellipsoidal geometries with major and minor axes respectively parallel to the systematic fractures and the dip directions. Part of the vesicles show collapsed cores that form craters with walls resistant to waves and tide erosion, while other cores are supported by the presence of dolomite;

- The vesicles have been traditionally interpreted as water escape structures triggered by the diapirism of the underlying shale of the Candeias Formation. This work introduces a new interpretation for the origin of such structures and assumes that vesicles would have been formed during massive gas hydrate dissociation as a result of tectonic activity in the Recôncavo paleolake system. Tectonism would have triggered a reduction of the confining pressure as well as an increase in lake bottom temperature, resulting both in the instability of hydrate nodules and in an intense release of methane - or $\mathrm{CO}_{2}$ - and water;

- In order to guarantee stable conditions for gas hydrate formation by the time of deposition of the Pitanga Member, bottom water temperatures in the tropical Recôncavo paleolake should be between $4^{\circ} \mathrm{C}$ and $20^{\circ} \mathrm{C}$ with a correspondent depth range of 400 to $2,000 \mathrm{~m}$, respectively. Uplift of the lake bottom would turn gas hydrate unstable and enhance dissociation, forming the fluid escape structures.

\section{ACKNOWLEDGEMENTS}

The authors are thankful to Renato Oscar Kowsmann, Otaviano da Cruz Pessoa Neto, Pierre Muzzi Magalhães for all valuable comments and for revising the manuscript. To Roberto Tinterri for discussions during a previous field trip occurred at the Maré Island. To Petrobras for the necessary given support, including laboratory analysis, field trip logistics and the formal authorization to publish the data. Thanks to Editor-in-Chief Dr. Umberto Cordani, Associate-Editor Dr. Gilmar Vital Bueno, and to the two anonymous reviewers for all the valuable comments.

\section{REFERENCES}

Barbosa da Silva O., Caixeta J.M., Milhomem P.S., Kosin M.D. 2007. Bacia do Recôncavo. Boletim de Geociências da Petrobras, 15(2):423-431

Caixeta J.M. 1988. Estudo faciológico e características de reservatório dos arenitos produtores de gás do Campo de Jacuípe (Cretáceo Inferior), Bacia do Recôncavo, Brasil. Dissertação de mestrado. Escola de Minas, Departamento de Geologia, Universidade Federal de Ouro Preto, Ouro Preto, 147p.

Collett T.S. 2002. Energy resource potential of natural gas hydrates. AAPG Bulletin, 86:1971-1992.

De Batist M., Klerkx J., Van Rensbergen P., Vanneste M., Poort J., Golmshtok A.Y., Kremlev A.A., Khlystov O.M., Krinitsky P. 2002. Active hydrate destabilization in Lake Baikal, Siberia? Terra Nova, 14(6):436-442
Denny M. 2008. How the ocean works: an introduction to oceanography. Princeton University Press, 320p.

Dickens G.R. 2001. Sulfate profiles and barium fronts in sediment on the Blake Ridge: present and past methane fluxes trough a large gas hydrate reservoir. Geochimica et Cosmochimica Acta, 65(4):529-543.

Edmonds B., Moorwood R., Szczepanski R. 1996. A practical model for the effect of salinity on gas hydrate formation. Society of Petroleum Engineers. European Production Operations Conference and Exhibition, 16-17 April, Stavanger, Norway. doi: 10.2118/35569-MS

Folk R.L. 1968. Petrology of sedimentary rocks. Hemphill Publishing Company. 190p. 
Freire A.F.M. 2010. An integrated study on the gas hydrate area of Joetsu Basin, eastern margin of Japan Sea, using geophysical, geological and geochemical data. PhD thesis. The University of Tokyo, Graduate School of Frontier Sciences, 247 pp.

Freire A.F.M., Matsumoto R., Santos L.A. 2011. Structural-stratigraphic control on the Umitaka Spur gas hydrates of Joetsu Basin in the eastern margin of Japan Sea. Marine and Petroleum Geology, 28:1967-1978

Freire A.F.M., Matsumoto R., Akiba F. 2012. Geochemical analysis as a complementary tool to estimate the uplift of sediments caused by shallow gas hydrates in mounds at the seafloor of Joetsu Basin, eastern margin of the Japan Sea. Journal of Geological Research, 2012:14 pages.

Ginsburg G.D. 1998. Gas hydrate accumulation in deep-water marine sediments. In: Henriet J.P. \& Mienert J. (eds.) Gas Hydrates. Relevance to World Margin Stability and Climatic Change. Geological Society London Special Publications, 137:51-62.

Greinert J., Bohrmann G., Suess E. 2001. Gas hydrate-associated carbonates and methane-venting at Hydrate Ridge: Classification, distribution, and origin of authigenic carbonates. In: Paull C.K. \& Dillon W.P. (eds.) Natural gas hydrates: Occurrence, distribution, and detection. American Geophysical Union, p. 99-113.

Haacke R.R., Hyndman R.D., Park K-P., Yoo D-G., Stoian I., Schmidt U. 2009. Migration and venting of deep gases into the ocean through hydrate-chocked chimneys Offshore Korea. Geology, 37(6):531-534.

Haq B.U. 1998. Natural gas hydrates: Searching for the long term climate and slope-stabilty records. In: Henriet J.-P. \& Mienert J. (eds.) Gas Hydrates: Relevance to World Margin Stability and Climate Change, The Geological Society, London, Special Publications, 137:303-318.

Hardage B.A. \& Roberts H.H. 2006. Gas hydrate in the Gulf of Mexico: What and where is the seismic target? The Leading Edge, May/2006:566-571

Hesselbo S.P., Gröcke D.R., Jenkyns H.C., Bjerrum C.J., Farrimond P., Morgans Bell H.S., Green O.R. 2000. Massive dissociation of gas hydrate during a Jurassic oceanic anoxic event. Nature, 406:392-395.

Hesselbo S.P., Jenkyns H.C., Duarte L.V., Oliveira L.C.V. 2007. Carbon-isotope record of the Early Jurassic (Toarcian) Oceanic Anoxic Event from fossil wood and marine carbonate (Lusitanian Basin, Portugal). Earth and Planetary Science Letters, 253:455-470.

Hoefs J. 2009. Stable Isotope Geochemistry. $6^{\text {th }}$ Ed. Springer-Verlag, Heidelberg-Berlin, Germany, 285p.

Hyndman H.D. \& Davis E.E. 1992. A mechanism for the formation of methane hydrate and seafloor bottom-simulating reflectors by vertical fluid expulsion. Journal of Geophysical Research, 97(B5):7025-7041.

Jenkyns H.C. 2003. Evidence for rapid climate change in the Mesozoic-Palaeogene greenhouse world. Philosophical Transaction of the Royal Society of London A, 361:1885-1916.

Jenkyns H.C. 2010. Geochemistry of oceanic anoxic events. Geochemistry, Geophysics, Geosystems, 11:3:1-30.

Krömmelbein K. 1962. Zur taxionomie und biochronologie stratigraphisch wichtiger Ostracoden - Arten aus der oberjurassisch ? - unterkretazischen Bahia-Serie (Wealden-Fazies) NE-Brasiliens. Senckenbergiana Lethaea, Frankfurt am Main, 43(6):437-528,

Kvenvolden K.A. 1993. Gas hydrates as a potential energy resource A review of their methane content. In: Howell D.G. (ed.) The Future of Energy Gases - U.S. Geological Survey Professional Paper 1570: Washington, United States Government Printing Office, p. 555-561.
Kvenvolden K.A. 1998. A primer on the geological occurrence of gas hydrate. In: Henriet J.P. \& Mienert J. (eds.) Gas hydrates: Relevance to world margin stability and climate change. Geological Society, London, Special Publications, 137:9-30.

Livingstone D.A. 1963. Chemical composition of rivers and lakes. In: Fleischer M. (ed.) Data of Geochemistry. $6^{\text {th }}$ ed. Chapter G. USGS, Washington.

Lowe D.R. \& Guy M. 2000. Slurry-Flow deposits in the Britannia Formation (Lower Cretaceous), North Sea: a new perspective on the turbidity current and debris flow problem. Sedimentology, 47:31-70.

Machel H.G., Sumrall J.B., Kambesis P.N., Mylroie J.E., Lac M.J. 2014. Episodic fluid flow and dolomitization by methane-bearing pore water of marine parentage in an accretionary prism setting, Barbados, West Indies. Journal of Sedimentary Research, 84:58-71.

Magalhães P.M. \& Tinterri R. 2010. Stratigraphy and depositional setting of slurry and contained beds in Marnoso-Arenacea Formation (Langhian-Serravallian) Northern Apennines, Italy. Sedimentology, 57:1685-1720.

Magnavita L.P. 1992. Geometry and kinematics of the Reconcavo-Tucano-Jatoba Rift, NE Brazil. PhD Thesis. Wolfson College, Earth Science Department, University of Oxford, Oxford. 742p.

Matsumoto R. 2005. Methane plumes over a marine gas hydrate system in the eastern margin of Japan Sea: A possible mechanism for the transportation of subsurface methane to shallow waters. Proceedings of the $5^{\text {th }}$ International Conference on Gas Hydrates, Trondhein, 749-754.

Matsumoto R., Freire A.F.M., Machiyama H., Satoh M., Hiruta A. 2009. Low velocity anomaly of gas hydrate bearing silty and clayey sediments, Joetsu Basin, Eastern Margin of Japan Sea. AOGS 2009 (Abstract) 4:529-543.

Mienert J. \& Posewang J. 1999. Evidence of shallow- and deep-water gas hydrate destabilizations in North Atlantic polar continental margin sediments. Geo-Marine Letters, 19:143-149.

Miller D.J., Ketzer J.M., Viana A.R., Kowsmann R.O., Freire A.F.M., Oreiro S.G., Augustin A.H., Lourega R.V., Rodrigues L.F., Heemann R., Preissler A.G., Machado C.X., Sbrissa G.F. 2015. Natural gas hydrates in the Rio Grande Cone (Brazil): A new province in the western South Atlantic. Marine and Petroleum Geology, 67:187-196.

Netto A.S.T. \& Oliveira J.J. 1985. O preenchimento do rift-valley na Bacia do Recôncavo. Revista Brasileira de Geociências, São Paulo, 15(2):97-102.

Orpin A.R. 1997. Dolomite chimneys as possible evidence of coastal fluid expulsion, uppermost Otago continental slope, Southern New Zeland. Marine Geology, 138:51-67.

Paull C.K., Borowsky W.S., Rodriguez N.M. 1998. Maine gas hydrate inventory: Preliminary results of ODP Leg 164 and implications for gas venting and slumping associated with the Blake Ridge gas hydrate field in Geological Society. London, Special Publications, 137:153-160.

Raja Gabaglia G.P. 1991. Paleossimicidade e sedimentação evidências no compartimento sul da Bacia do Recôncavo, Bahia. Boletim de Geociências da Petrobrás, 5(1/4):39-68.

Sabatino N., Neri R., Bellanca A., Jenkyns H.C., Baudin F., Parisi G., Masetti D. 2009. Carbon-isotope records of the Early Jurassic (Toarcian) oceanic anoxic event from the Valdorbia (Umbria-Marche Apennines) and Monte Mangart (Julian Alps) sections: palaeoceanographic and stratigraphic implications. Sedimentology, 56:1307-1328 
Scherer C.M.S. 2007. Arquitetura estratigráfica, geometria e heterogeneidades dos arenitos reservatórios da Formação Maracangalha, Bacia do Reconcavo, Bahia. Projeto CTPETRO/ FINEP - PETROBRAS/ Universidade Federal da Bahia/ Universidade Federal da Bahia, 265p.

Serié C., Huuse M., ShØdt N.H. 2012. Gas hydrate pingoes: Deep seafloor evidence of focused fluid flow on continental margins. Geology, v.40, n.3:207-210

Sharp Z. 2007. Principles of stable isotope geochemistry. Pearson Prentice Hall, Upper Saddle River, New Jersey.

Silva H.T.F. 1993. Flooding surfaces, depositional elements and accumulation rates - characteristics of the Lower Cretaceous Tectonosequence in the Reconcavo Basin, northeast Brazil. PhD thesis. Texas University, 311p.

Sloan Jr. E.D. 2003. Fundamental principles and applications of natural gas hydrates. Nature, 426:353-359.

Snyder G.T., Hiruta A., Matsumoto R., Dickens G.R., Tomaru H. Tackeuchi R., Komatsubara J., Ishida Y., Yu H. 2007. Pour water profiles and authigenic mineralization in shallow marine sediments above the methane-charged system on Umitaka Spur, Japan Sea. Deep-Sea Research II, 54:1216-1239.
Suess E., Torres M.E., Bohrmann G., Collier R.W., Greinert J., Linke P., Rehder G., Trehu A., Wallmann K., Winckler G., Zuleger E. 1999. Gas hydrate destabilization: enhanced dewatering, benthic material turnover and large methane plumes at the Cascadia convergent margin. Earth and Planetary Science Letters, 170:1-15.

Tinterri R. \& Tagliaferri A. 2015. The syntectonic evolution of foredeep turbidites related to basin segmentation: Facies response to the increase in tectonic confinement (Marnoso-arenacea Formation, Miocene, Northern Apennines, Italy). Marine and Petroleum Geology, 67:81-110

Vanneste M., De Batisti M., Golmshtoc A., Kremlev A., Versteeg W. 2001. Multi-frequency seismic study of gas hydrate-bearing sediments in Lake Baikal, Siberia. Marine Geology, 172:1-21.

Wicher C.A. 1959. Ein Beitrag zur Altersdeutung des Reconcavo, Bahia (Brasilien). Geologisches Jahrbuch, Hannover, 77:35-78.

Available at www.sbgeo.org.b 